\title{
Thiohalorhabdus denitrificans gen. nov., sp. nov., an extremely halophilic, sulfur-oxidizing, deep-lineage gammaproteobacterium from hypersaline habitats
}

\author{
Correspondence \\ Dimitry Yu. Sorokin \\ soroc@inmi.host.ru \\ or \\ d.y.sorokin@tudelft.nl
}

\author{
Dimitry Yu. Sorokin, ${ }^{1,2}$ Tatjana P. Tourova, ${ }^{1}$ Erwin A. Galinski, ${ }^{3}$ \\ Gerard Muyzer ${ }^{2}$ and J. Gijs Kuenen ${ }^{2}$ \\ ${ }^{1}$ Winogradsky Institute of Microbiology, Russian Academy of Sciences, Prospect 60-let Octyabrya \\ 7/2, 117811 Moscow, Russia \\ ${ }^{2}$ Department of Biotechnology, Delft University of Technology, Julianalaan 67, 2628 BC Delft, \\ The Netherlands \\ ${ }^{3}$ Institute of Microbiology and Biotechnology, Rheinische Friedrich-Wilhelms University, Bonn, \\ Germany
}

\begin{abstract}
Seven strains of extremely halophilic and obligately chemolithoautotrophic sulfur-oxidizing bacteria (SOB) were enriched and isolated at $4 \mathrm{M} \mathrm{NaCl}$ from sediments of hypersaline inland lakes in south-eastern Siberia and a Mediterranean sea solar saltern. Cells of the novel isolates were spindle-like, long and non-motile rods with a Gram-negative type of cell wall. They were obligately chemolithoautotrophic SOB using thiosulfate and tetrathionate as electron donors and represent the first example of extremely halophilic chemolithoautotrophs that are able to grow anaerobically with nitrate as electron acceptor. The characteristic feature of the group was the production of large amounts of tetrathionate as an intermediate during the oxidation of thiosulfate to sulfate. With thiosulfate, the novel strains grew within the $\mathrm{pH}$ range from 6.5 to 8.2 (optimum at $\mathrm{pH} 7.5-7.8$ ) and at $\mathrm{NaCl}$ concentrations from 1.5 to $4.0 \mathrm{M}$ (optimum at $3.0 \mathrm{M}$ ). Cells grown at $4 \mathrm{M} \mathrm{NaCl}$ accumulated extremely high concentrations of glycine betaine as a compatible solute. The dominant cellular fatty acids were $10 \mathrm{MeC}_{16: 0}$ and $\mathrm{C}_{16: 0}$. Based on the DNA-DNA relatedness values, the isolates consisted of a single genomic species and had a similar phenotype. Phylogenetic analysis placed the novel bacteria in the class Gammaproteobacteria as an independent lineage with no significant relationship to any other genera in this class. On the basis of phenotypic and genotypic analysis, the group is proposed to represent a new genus, Thiohalorhabdus gen. nov., with Thiohalorhabdus denitrificans gen. nov., sp. nov. as the type species (type strain HL $19^{\top}=$ DSM $15699^{\top}=$ UNIQEM U223 ${ }^{\top}$ ).
\end{abstract}

Chemolithoautotrophic sulfur-oxidizing bacteria (SOB) represent an important functional group responsible for the recycling of reduced inorganic sulfur compounds produced by sulfidogenic prokaryotes in anaerobic zones. Their usual habitat is the oxygen-sulfide interface. Until now, little has been known about the activity of this group in hypersaline habitats. Recent investigations of the culturable diversity of SOB in hypersaline inland lakes, sea solar salterns and deep-sea brines with neutral $\mathrm{pH}$ have revealed the presence of six lineages of obligately chemolithoautotrophic SOB, all belonging to the class

Abbreviation: SOB, sulfur-oxidizing bacteria.

The GenBank/EMBL/DDBJ accession numbers for the 16S rRNA gene sequences obtained in this study are DQ469582-DQ469583 and EU374710-EU374713.
Gammaproteobacteria (Sorokin et al., 2006a; Sorokin, 2008). Four of the lineages are moderate halophiles, including two groups of aerobes from the well known genera Thiomicrospira (Sorokin et al., 2006b) and Halothiobacillus (unpublished results) as well as two novel genera of facultatively anaerobic thiodenitrifiers, Thiohalomonas (Sorokin et al., 2007a) and Thiohalophilus (Sorokin et al., 2007b). The other two groups are extremely halophilic ecotypes that have not been isolated before. Their properties are extraordinary not only among the $\mathrm{SOB}$, but also among all other known representatives of chemolithoautotrophic prokaryotes. The aerobic group of these extreme halophiles has recently been described as a novel genus Thiohalospira (Sorokin et al., 2008). The facultative denitrifiers among these extremely halophilic $\mathrm{SOB}$ are the subject of the present paper. 
Surface sediments from hypersaline lakes in north-east Mongolia, Kulunda Steppe (south-west Siberia, Altai, Russia), Crimea (Ukraine), from lake Baskunchak (South Russia) and from the Sečovlje Adriatic Sea solar saltern (Slovenia) were used in this study (Sorokin et al., 2006a). The total salt concentration of the brines varied from 20 to $38 \%(\mathrm{w} / \mathrm{v})$ and the $\mathrm{pH}$ ranged from 6.5 to 8.5 ; the dominant ions were $\mathrm{Na}^{+}, \mathrm{Mg}^{2+}, \mathrm{Cl}^{-}$and $\mathrm{SO}_{4}^{2-}$.

The following organic-free mineral base medium was used for the enrichment and growth experiments: $4.0 \mathrm{M} \mathrm{NaCl}$, $10 \mathrm{mM} \mathrm{K}_{2} \mathrm{HPO}_{4}$ and $5 \mathrm{mM} \mathrm{NH}_{4} \mathrm{Cl}$. The $\mathrm{pH}$ was adjusted to 7.5 with $10 \% \mathrm{KH}_{2} \mathrm{PO}_{4}$. After sterilization, the medium was supplemented with $2 \mathrm{mM} \mathrm{MgCl}_{2} \cdot 6 \mathrm{H}_{2} \mathrm{O}$ and $1 \mathrm{ml} \mathrm{l}^{-1}$ trace metal solution (Pfennig \& Lippert, 1966). Thiosulfate $(20 \mathrm{mM})$ or tetrathionate $(5 \mathrm{mM})$ were added as electron donors from filter-sterilized $1 \mathrm{M}$ solutions. Nitrate and nitrite were used as electron acceptors at final concentrations of 5 and $2 \mathrm{mM}$, respectively. Filter-sterilized $\mathrm{NaHCO}_{3}(1 \mathrm{M}$, $\mathrm{pH}$ 8.0) was added as a carbon source and as a $\mathrm{pH}$ buffer to give final concentrations of $20-40 \mathrm{mM}$. Routine aerobic incubation was performed in closed bottles with the liquid/ gas ratio $10: 90$ to prevent loss of $\mathrm{CO}_{2}$ from $\mathrm{NaHCO}_{3}$, which would have resulted in spontaneous alkalinization of the medium during the initial growth phase. In order to create micro-aerobic conditions, the gas phase contained 2-5\% $\mathrm{O}_{2}$. For anaerobic incubations, serum flasks with butyl rubber stoppers were filled with ready-to-use medium up to $70 \%$ and subjected to 3 cycles of evacuation/flushing with argon. Cultivation was performed at $28{ }^{\circ} \mathrm{C}$. The cultures were made anoxic by first replacing the gas phase by argon; the $50 \%$ argon was then replaced either by $\mathrm{H}_{2}$ or $\mathrm{N}_{2} \mathrm{O}$ to study their utilization. Growth was monitored by following the optical density at $590 \mathrm{~nm}$, substrate consumption and product formation. Pure cultures were obtained after several rounds of serial dilutions to exhaustion on liquid media, since none of the isolates formed colonies on solid media. Culture purity was checked on rich organic medium where the inorganic electron donor was replaced by yeast extract.

The sulfur (sulfide, sulfur, thiosulfate, tetrathionate and sulfate) and nitrogen (nitrate, nitrite and $\mathrm{N}_{2} \mathrm{O}$ ) compounds were analysed as described previously (Sorokin et al., 2001). Cell protein was measured by the Lowry method after removal of interfering sulfur compounds either by washing (thiosulfate, tetrathionate) or by overnight extraction with acetone (sulfur). Phase-contrast microphotographs were obtained using a Zeiss Axioplan Imaging 2 microscope. For electron microscopy, the cells were prefixed in glutaraldehyde (final concentration $3 \% \mathrm{v} / \mathrm{v}$ ) at $\mathrm{pH} 7.0$ in the presence of $2 \mathrm{M} \mathrm{NaCl}$, then post-fixed in $1 \%$ $(\mathrm{w} / \mathrm{v}) \mathrm{OsO}_{4} / 2.0 \mathrm{M} \mathrm{NaCl}$ for $12 \mathrm{~h}$ at room temperature, washed and stained overnight with $1 \%(\mathrm{w} / \mathrm{v})$ uranyl acetate, dehydrated in an ethanol series and embedded in Epon resin. Thin sections were contrasted with $1 \%(\mathrm{w} / \mathrm{v})$ lead citrate. Other analyses (such as respiration tests and activity measurements) were performed as described previously (Sorokin et al., 2008).

Anaerobic enrichments with thiosulfate as the electron donor at $4 \mathrm{M} \mathrm{NaCl}$ gave positive results only when nitrate (but not nitrite or $\mathrm{N}_{2} \mathrm{O}$ ) served as the electron acceptor. The cultures were characterized by extremely slow growth and copious accumulation of intermediates, including cellassociated sulfur from thiosulfate and nitrite from nitrate. Cultures were dominated by long slim rods. Overall, five pure cultures (HLD 7-HLD 11) were obtained from denitrifying enrichments inoculated with sediments from the Kulunda Steppe lakes and a sea solar saltern (Table 1). Two more strains were obtained from aerobic enrichment cultures at $4 \mathrm{M} \mathrm{NaCl}$, where, for unknown reasons, the aerobic extremely halophilic SOB of the genus Thiohalospira (Sorokin et al., 2008) were not detectable. Strain HL $19^{\mathrm{T}}$ became dominant in a mixotrophic enrichment from Kulunda Steppe lake sediments with acetate and thiosulfate at $4 \mathrm{M} \mathrm{NaCl}$. During the first stage of this enrichment, a heterotrophic haloarchaeon consumed the acetate with a concomitant unspecific transformation of thiosulfate to tetrathionate (Sorokin et al., 2005). The latter was further utilized by a mixture of extremely halophilic chemolithoautotrophic SOB. One of the ensuing dominant rod-shaped phenotypes (strain HL $19^{\mathrm{T}}$ ) was isolated in pure culture using tetrathionate as the substrate. Another similar strain, HL 28, was isolated from a microaerobic enrichment culture at $4 \mathrm{M} \mathrm{NaCl}$ with thiosulfate from sediments of a Crimean lake. Both strains HL $19^{\mathrm{T}}$ and HL 28 , isolated as aerobes, showed an ability to grow anaerobically with nitrate, and were thus of the same phenotype as the HLD strains (Table 1).

Table 1. Pure cultures of extremely halophilic denitrifying $\mathrm{SOB}$, enriched and isolated at $4 \mathrm{M} \mathrm{NaCl}$

\begin{tabular}{|c|c|c|c|c|}
\hline Region & Habitat & Enrichment & Strains & $\begin{array}{c}\text { DNA G + C } \\
\text { content }(\mathrm{mol} \%)\end{array}$ \\
\hline \multirow[t]{3}{*}{ Kulunda Steppe (Altai, Russia) } & \multirow[t]{3}{*}{ Salt lakes } & \multirow{3}{*}{ Anaerobic with $\mathrm{S}_{2} \mathrm{O}_{3}^{2-} / \mathrm{NO}_{3}^{-}$} & HLD 7 & 65.1 \\
\hline & & & HLD 10 & 65.8 \\
\hline & & & HLD 11 & 65.0 \\
\hline Crimea Peninsula (Ukraine) & Salt lakes & Aerobic with $\mathrm{S}_{2} \mathrm{O}_{3}^{2-}$ & HL 28 & 65.5 \\
\hline
\end{tabular}


All seven isolates were represented by thin, long, spindlelike, non-motile rods with pointed ends. In anaerobic nitrate-reducing cultures, cells accumulated large sulfur globules, most probably in the periplasm (Fig. 1).
Experiments with strain HL $19^{\mathrm{T}}$ clearly demonstrated its obligate dependence on high sodium and chloride concentrations. Growth was completely inhibited when $35 \% \mathrm{Na}^{+}$was replaced by $\mathrm{K}^{+}$(at $4 \mathrm{M}$ total, i.e. $2.6 \mathrm{M}$
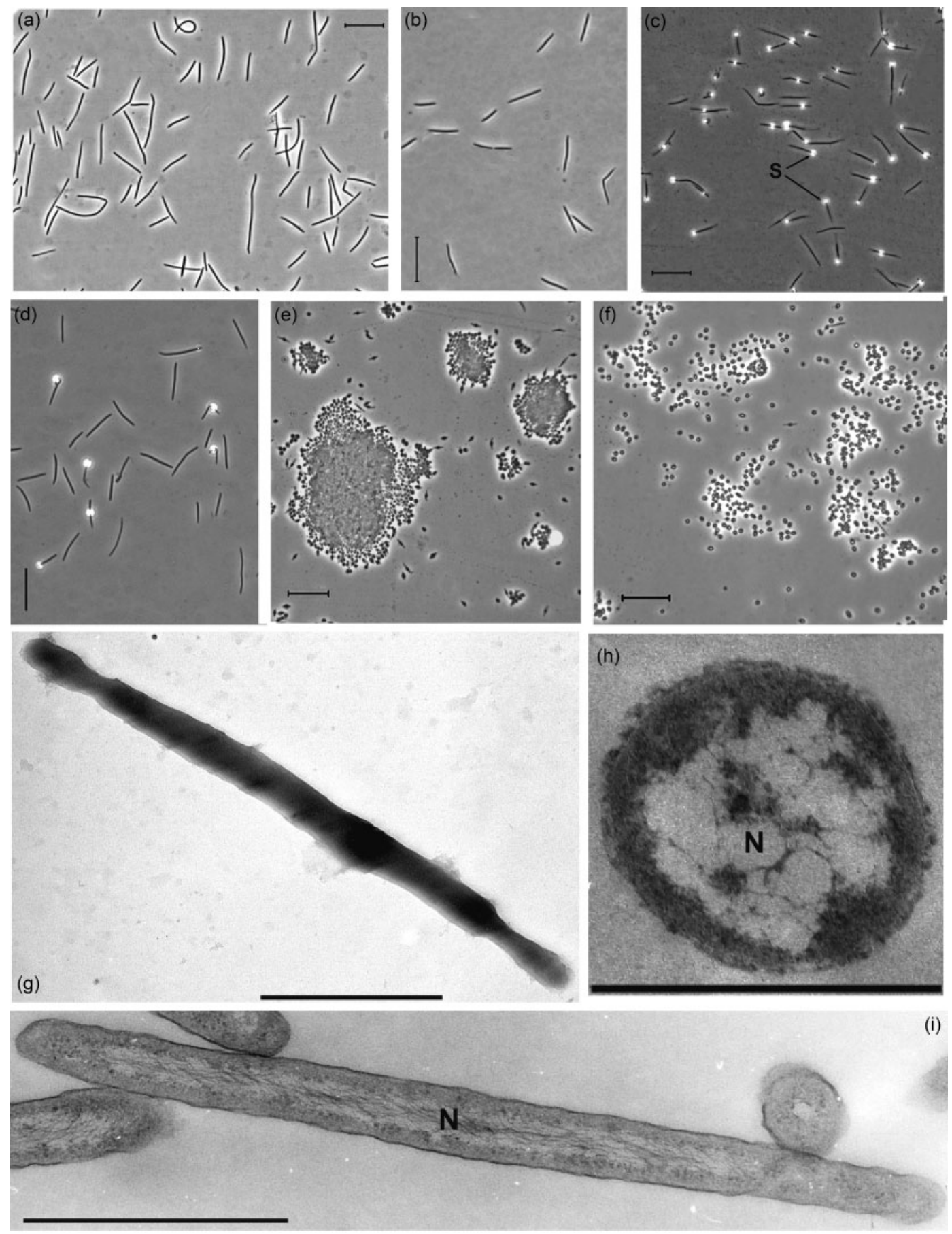

Fig. 1. Cell morphology of the novel strains grown with $4 \mathrm{M} \mathrm{NaCl}$. Images are phase-contrast micrographs (a-f), electron micrographs of thin sections ( $\mathrm{h}$ and $\mathrm{i}$ ) and electron micrographs of fixed, intact cells (g). (a), Cells of strain $\mathrm{HL}_{1} 9^{\top}$ from aerobic culture; (e, f, h), cyst-like structures formed in aerobic cultures limited by $\mathrm{Na}^{+}$or $\mathrm{Cl}^{-}$. (b), Cells of strain $\mathrm{HL} 28$ (aerobic). (c, d), Cells of strains HLD 7 and HLD 18 (anaerobic), respectively. (e-i), Cells of strain HL $19^{\top}$. N, Nucleoid; S, cell-associated sulfur globules formed during incomplete thiosulfate oxidation in anaerobic cultures. Bars, $10 \mu \mathrm{m}(\mathrm{a}-\mathrm{f}) ; 1 \mu \mathrm{m}(\mathrm{g}-\mathrm{i})$. 
$\mathrm{NaCl} / 1.4 \mathrm{M} \mathrm{KCl})$ and at $70 \%$ replacement of chloride by sulfate (by charge, $2 \mathrm{Cl}^{-}=1 \mathrm{SO}_{4}^{2-}$; i.e. $1.2 \mathrm{M} \mathrm{NaCl} / 1.4 \mathrm{M}$ $\mathrm{Na}_{2} \mathrm{SO}_{4}$ ). At lower levels of replacement, the culture was able to grow but the cells were transformed from long rods into round cyst-like bodies (Fig. 1e, $\mathrm{f}, \mathrm{h}$ ), readily reverting back to normal shape upon the removal of $\mathrm{Na} / \mathrm{Cl}$ limitation. A similar phenomenon was observed in cultures of the genus Thiohalomonas, which are moderately halophilic thiodenitrifiers from the same habitats (Sorokin et al., 2007a).

The novel bacterial strains were obligately chemolithoautotrophic SOB, growing with thiosulfate and tetrathionate both aerobically and anaerobically in the presence of nitrate as electron acceptor. We did not manage to grow strains HL $19^{\mathrm{T}}$ and HLD 8 anaerobically with sulfide as the electron donor and nitrate as the acceptor. However, these strains did form a dense cell/sulfur band in the sulfideoxygen gradient cultures containing $3 \mathrm{M} \mathrm{NaCl}$ in a similar manner to that found for strains of the genus Thiohalospira (Sorokin et al., 2008). Together with the ability of the washed cells to respire with sulfide (see below), this observation can be taken as an indication of the potential to use sulfide as an electron donor. Hydrogen and thiocyanate were not utilized as electron donors. Only strain HL $19^{\mathrm{T}}$ grew under fully aerobic conditions, while the other six isolates preferred micro-aerobic conditions $\left(2-5 \% \mathrm{O}_{2}\right)$ and did not grow when the gas phase contained $>10 \% \quad \mathrm{O}_{2}$. The maximum experimentally measured growth yield and specific growth rate during aerobic growth on thiosulfate in cultures of strain $\mathrm{HL} 19^{\mathrm{T}}$ at $3 \mathrm{M}$ $\mathrm{NaCl}$ were $4.2 \mathrm{mg}$ protein $\left(\mathrm{mmol} \mathrm{S}_{2} \mathrm{O}_{3}^{2-}\right)^{-1}$ and $0.052 \mathrm{~h}^{-1}$, respectively.

A characteristic feature of the novel strains was the formation of significant concentrations of tetrathionate during aerobic growth with thiosulfate, which, eventually, was oxidized further to sulfate (Fig. 2a). A similar behaviour has been observed in a recently described extremely halophilic SOB Thiohalospira halophila (Sorokin et al., 2008). Tetrathionate formation is commonly known as an overflow mechanism observed in aerobic enrichments of thiosulfate-oxidizing bacteria. It also often occurs in pure batch cultures under conditions of excess thiosulfate. However, massive formation of tetrathionate from thiosulfate in lithotrophic SOB is common only in extreme acidiphiles. Apart from thiosulfate and tetrathionate, sulfide and elemental sulfur can also be oxidized by cells grown with thiosulfate. The rates of oxygen consumption at $4 \mathrm{M} \mathrm{NaCl}$ as measured in four strains were $150-500,100-280,140-480$ and $60-100 \mathrm{nmol}$ $\mathrm{O}_{2}$ (mg protein $)^{-1} \mathrm{~min}^{-1}$ with thiosulfate, tetrathionate, sulfide and sulfur (solution in acetone), respectively. The thiosulfate-acceptor oxidoreductase activity (tetrathionate synthase), as tested in cell-free extracts of four strains, was located in the soluble fraction and functioned optimally at $\mathrm{pH}$ values of below 7 in $\mathrm{NaCl}$ brines. Replacement of $\mathrm{Na}^{+}$ by $\mathrm{K}^{+}$led to $70 \%$ reduction in activity, while $\mathrm{Cl}^{-}$ replacement caused $100 \%$ inhibition. At optimal condi- (a)
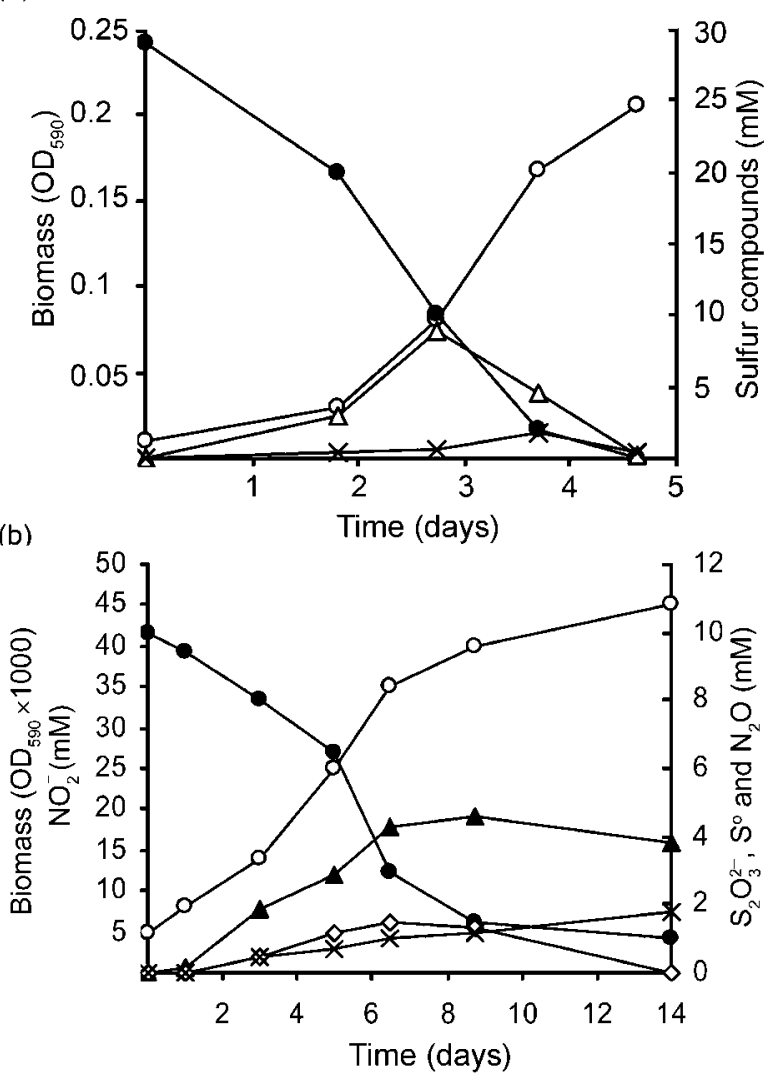

Fig. 2. Growth and product formation with $3 \mathrm{M} \mathrm{NaCl}$ in aerobic (a) and anaerobic (b) cultures of strain HLD $19^{\top}$ with thiosulfate. $\bigcirc$, Biomass; $\bullet$, thiosulfate; $\triangle$, tetrathionate; $\boldsymbol{\Delta}$, nitrite; $\diamond, \mathrm{N}_{2} \mathrm{O} ; \times$, sulfur.

tions ( $\mathrm{pH} 6.0,4 \mathrm{M} \mathrm{NaCl}$ ), activity with ferricyanide as the electron acceptor was very high, ranging from 5 to $20 \mu \mathrm{mol}$ $(\mathrm{mg} \text { protein })^{-1} \min ^{-1}$.

Anaerobic growth with nitrate resulted in a very high level of nitrite formation and a much lower level of $\mathrm{N}_{2} \mathrm{O}$, while most of the thiosulfate was converted to sulfate with some accumulation of cell-bound elemental sulfur. In contrast to aerobic cultures, no tetrathionate formation was observed during anaerobic growth (Fig. 2b). Apparently, under denitrifying conditions, the oxidation of intermediates other than tetrathionate (i.e. the oxidation of bound polysulfide) becomes the rate-limiting step. To clarify whether the novel bacteria were unable to reduce nitrite further, cells grown anaerobically with nitrate were concentrated, washed and incubated with thiosulfate in the presence of nitrate, nitrite and $\mathrm{N}_{2} \mathrm{O}$ for several hours. Thiosulfate-dependent reduction was detected for all three nitrogen oxides but with definite superiority of nitrate and $\mathrm{N}_{2} \mathrm{O}$ reduction. In strains HLD 8 and HLD 10, the reduction rates were $320-670 \mathrm{nmol} \mathrm{NO}{ }_{3}^{-}(\mathrm{mg} \text { protein })^{-1}$ $\min ^{-1}, 1.5-2.2 \mathrm{nmol} \mathrm{NO}{ }_{2}^{-}$(mg protein ${ }^{-1} \min ^{-1}$ and 180-300 nmol $\mathrm{N}_{2} \mathrm{O}$ (mg protein) ${ }^{-1} \mathrm{~min}^{-1}$. These data 
indicate that a very low activity of nitrite reductase is the bottleneck for the whole denitrification process in the extremely halophilic thiodenitrifiers.

Given their salt requirement, the novel thiodenitrifying strains belong to the extreme halophiles and only a single similar example, Thiohalospira halophila, is known so far among the aerobic chemolithoautotrophs. The $\mathrm{NaCl}$ range for growth was from 1.5-2.0 to $5.0 \mathrm{M}$ with an optimum at 3.0 M (Fig. 3a). The respiratory activity of washed cells, both aerobic and anaerobic, and the activity of thiosulfate dehydrogenase in cell-free extract were optimal at extremely high salt concentrations between 2.5 and $4 \mathrm{M}$ $\mathrm{NaCl}$. In contrast to growing cultures, washed cells were still partially active at a salinity lower than $2 \mathrm{M}$ but they started to lyse rapidly below $1.5 \mathrm{M} \mathrm{NaCl}$ (Fig. 3b). The pH values suitable for aerobic growth with thiosulfate for strains HL $19^{\mathrm{T}}$, HLD 8, HL 28 and HLD 18 were within the range 6.5-8.2 with an optimum between 7.3 and 7.8.

(a)
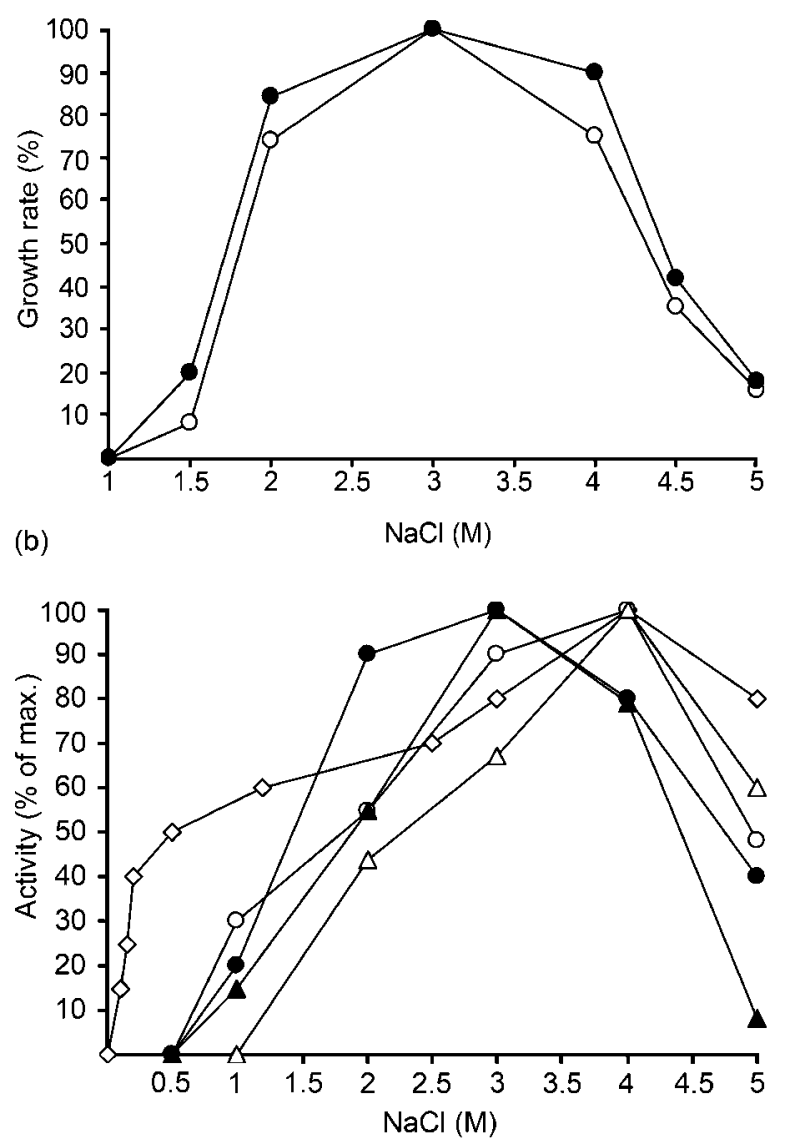

Fig. 3. Influence of $\mathrm{NaCl}$ on (a) aerobic growth of strains $\mathrm{HL} 19^{\top}$ and HLD 8 with thiosulfate at $\mathrm{pH} 7.5, \bigcirc, \mathrm{HL} 19^{\top} ; \bullet, H L D$; and (b) on activity of thiosulfate oxidation by washed cells of strain HLD 8 at $\mathrm{pH} 7.5, \bigcirc$, aerobic; $\bullet$, anaerobic with nitrate; $\triangle$, anaerobic with nitrite; $\boldsymbol{\Delta}$, anaerobic with $\mathrm{N}_{2} \mathrm{O} ; \diamond$, activity of tetrathionate synthase in cell-free extract at $\mathrm{pH} 6$.
Cellular fatty acids were extracted from freeze-dried biomass of strain $\mathrm{HL} 19^{\mathrm{T}}$ grown at $4 \mathrm{M} \mathrm{NaCl}$ and $30{ }^{\circ} \mathrm{C}$ with thiosulfate by acidic methanol and were analysed by GC-MS according to Zhilina et al. (1997). The analysis demonstrated that two saturated species dominated with $10 \mathrm{MeC}_{16: 0}$ and $\mathrm{C}_{16: 0}$ constituting $>70 \%$ of the total fatty acids. The fatty acid composition was very similar to that already found for another extremely halophilic SOB, Thiohalospira halophila grown at the same salinity (Sorokin et al., 2008), even though they have distant phylogenetic positions (see below), but was clearly different from other moderately halophilic SOB (Table 2).

Organic compatible solutes were extracted from the freezedried cells of strain $\mathrm{HL} 19^{\mathrm{T}}$ grown at $4 \mathrm{M} \mathrm{NaCl}$ and $30{ }^{\circ} \mathrm{C}$ on organic-free mineral medium with thiosulfate as the electron donor and $\mathrm{HCO}_{3}{ }^{-}$as the carbon source and were further analysed by HPLC as described previously (Banciu et al., 2004). A single compound, glycine betaine, was detected, constituting $30 \%$ of the total cell mass. This result was also very similar to that observed for the genus Thiohalospira (Sorokin et al., 2008).

Spectroscopic analysis of cell fractions of strains HL $19^{\mathrm{T}}$ and HLD 11 grown aerobically with thiosulfate identified cytochrome $c_{553}$ as the major cytochrome both in the membranes and in the soluble fraction and the presence of a CO-binding cytochrome $b_{563}$ was also found in the membranes. Addition of thiosulfate to the soluble fraction resulted in the reduction of two additional cytochromes $c$ with alpha peaks at 549 and $554 \mathrm{~nm}$ (data not shown).

Genomic DNA was extracted by the phenol/chloroform method (Marmur, 1961). The DNA G+C content determination and DNA-DNA hybridization were performed by the thermal denaturation/reassociation technique (Marmur \& Doty, 1962; De Ley et al., 1970) using Escherichia coli as a standard. The isolates had a very similar DNA G +C content, between 65.0 and $65.8 \mathrm{~mol} \%$ $\left(T_{\mathrm{m}}\right)$ (Table 1). According to the DNA-DNA hybridization results, the novel strains, despite having been isolated from different geographical locations, formed a single genomic species with DNA-DNA relatedness values of $70-85 \%$. The strains from Kulunda Steppe had the highest DNA-DNA relatedness (above $80 \%$ ) with each other and the lowest value $(70 \%)$ was obtained between strain $\mathrm{HL} 19^{\mathrm{T}}$ and the isolate from the saltern, HL 28.

The nearly complete 16S rRNA gene was amplified from pure cultures using general bacterial primers GM3F and GM4R (Schäfer \& Muyzer, 2001). The PCR products were purified from low-melting point agarose using the Wizard PCR-Prep kit (Promega) according to the manufacturer's instructions. Sequencing was performed using Big Dye Terminator v3.1 sequencing reaction kit with an ABI 3730 DNA automatic sequencer (Applied Biosystems). The sequences were aligned with those from GenBank using CLUSTAL W. Phylogenetic trees were reconstructed with four different algorithms using the TREECON W (van de Peer \& De Wachter, 1994) and PHYLIP 3.5c (Felsenstein, 1993) 
Table 2. Comparison of the fatty acid content of the polar lipids for Thiohalorhabdus denitrificans gen. nov., sp. nov. HL $19^{\top}$ with other halophilic SOB lineages from hypersaline habitats

Values are \% of total fatty acids. NP, Not present. Data for the genera Thiohalospira, Thiohalomonas and Thiohalophilus are from Sorokin et al. (2007a, b, 2008). Values in bold type represent the major fatty acids for each taxon.

\begin{tabular}{|c|c|c|c|c|}
\hline \multirow[t]{2}{*}{ Fatty acid } & \multicolumn{2}{|c|}{ Extreme halophiles } & \multicolumn{2}{|c|}{ Moderate halophiles } \\
\hline & Thiohalorhabdus & Thiohalospira & Thiohalomonas & Thiohalophilus \\
\hline $\mathrm{C}_{16: 1} \omega 5$ & $\mathrm{NP}$ & $\mathrm{NP}$ & 3.0 & 0.2 \\
\hline $\mathrm{C}_{16: 0}$ & 29.4 & 31.9 & 25.4 & 33.7 \\
\hline $10 \mathrm{MeC}_{16}$ & 43.4 & 44.5 & 1.3 & NP \\
\hline $\mathrm{C}_{17} \mathrm{cyc}$ & NP & NP & 8.4 & 0.2 \\
\hline $\mathrm{C}_{18: 1} \omega 9$ & 0.3 & NP & 5.1 & 0.1 \\
\hline $\mathrm{C}_{18: 1} \omega 7$ & 3.4 & 5.8 & 11.8 & 1.1 \\
\hline $\mathrm{C}_{18: 0}$ & 3.4 & 3.3 & 0.5 & 0.2 \\
\hline $\mathrm{C}_{19} \mathrm{cyc}$ & NP & NP & 3.3 & NP \\
\hline
\end{tabular}

software packages. Pairwise evolutionary distances (expressed as estimated changes per 100 nucleotides) were computed by using the Jukes \& Cantor method. The resulting phylogenetic tree was constructed by the neighbour-joining method. Bootstrap analysis (1000 replications) was used to estimate the reproducibility of the branching patterns of the trees.

Analysis of the 16S rRNA gene sequences of the six novel strains demonstrated that they formed a compact group representing a new deep lineage within the class Gammaproteobacteria virtually unrelated to any other group in this class of bacteria (Fig. 4). The sequence similarity between the novel strains was $98.5-99 \%$, confirming the conclusion from the DNA-DNA hybridization data that they constituted a single genotype. The cluster also included environmental sequences obtained recently from a hypersaline mat community (sea solar saltern, Puerto Rico) with a novel molecular approach (miniprimer PCR) (Isenbarger et al., 2008). The sequence similarity of the novel bacteria to other culturable representatives of the class Gammaproteobacteria (genera Thiohalomonas, Thiohalospira, Alkalispirillum and Halorhodospira) was not higher than $88 \%$. These results indicated that the new isolates formed a novel cluster that might represent a novel family or even an order level within the class Gammaproteobacteria.

The data presented in this study demonstrate the unique features of the extremely halophilic group of thiodenitrifying SOB from hypersaline habitats. Despite being isolated from different types of hypersaline habitats, such as inland athalassohaline lakes, thalassohaline lakes and a solar thalassohaline saltern, all seven isolates shared a high level of genotypic and phenotypic similarity. It is suggested that these strains represent a new genus and novel species for which the name Thiohalorhabdus denitrificans gen. nov., sp. nov. is proposed.

\section{Description of Thiohalorhabdus gen. nov.}

Thiohalorhabdus (Thi.o.ha.lo.rhab'dus. Gr. n. thion sulfur; Gr. n. hals halos salt; Gr. fem. n. rhabdos rod, stick; N.L. fem. n. Thiohalorhabdus halophilic sulfur rod).

Long rods with a Gram-negative cell wall. Obligately chemolithoautotrophic and facultatively anaerobic (denitrifying) sulfur-oxidizing bacteria. Oxidize inorganic sulfur compounds to sulfate. Tetrathionate and elemental sulfur are the usual intermediates of thiosulfate oxidation. Extremely halophilic and neutrophilic. Major cellular fatty acids are $10 \mathrm{MeC}_{16: 0}$ and $\mathrm{C}_{16: 0}$. Isolated from hypersaline habitats. A member of the class Gammaproteobacteria. The type species is Thiohalorhabdus denitrificans.

\section{Description of Thiohalorhabdus denitrificans sp. nov.}

Thiohalorhabdus denitrificans (de.ni.tri'fi.cans. N.L. v. denitrifico denitrify; N.L. part. adj. denitrificans denitrifying).

The main characteristics are as those given in the genus description. Cells are long, slender, non-motile rods with pointed ends, $0.3-0.4 \times 3-12 \mu \mathrm{m}$. The dominant cellular fatty acids include $10 \mathrm{MeC}_{16: 0}, \mathrm{C}_{16: 0}$ and $\mathrm{C}_{16: 1} \omega 7$. Accumulates large amounts of glycine betaine as a compatible solute. Oxidizes thiosulfate aerobically to sulfate through tetrathionate and anaerobically through elemental sulfur. Grows anaerobically with thiosulfate or tetrathionate as electron donors and nitrate as electron acceptors. Grows with sulfide in sulfide-oxygen gradient cultures. Nitrite is the major intermediate of nitrate reduction. Is also able to oxidize sulfide and elemental sulfur, but not $\mathrm{H}_{2}$. Extremely halophilic with a salinity range for growth from 2.0 to $5.0 \mathrm{M} \mathrm{NaCl}$ and an optimum at $3.0 \mathrm{M}$. Absolute requirement for high concentrations of both $\mathrm{Na}^{+}$and $\mathrm{Cl}^{-}$. The $\mathrm{pH}$ range for growth is between 


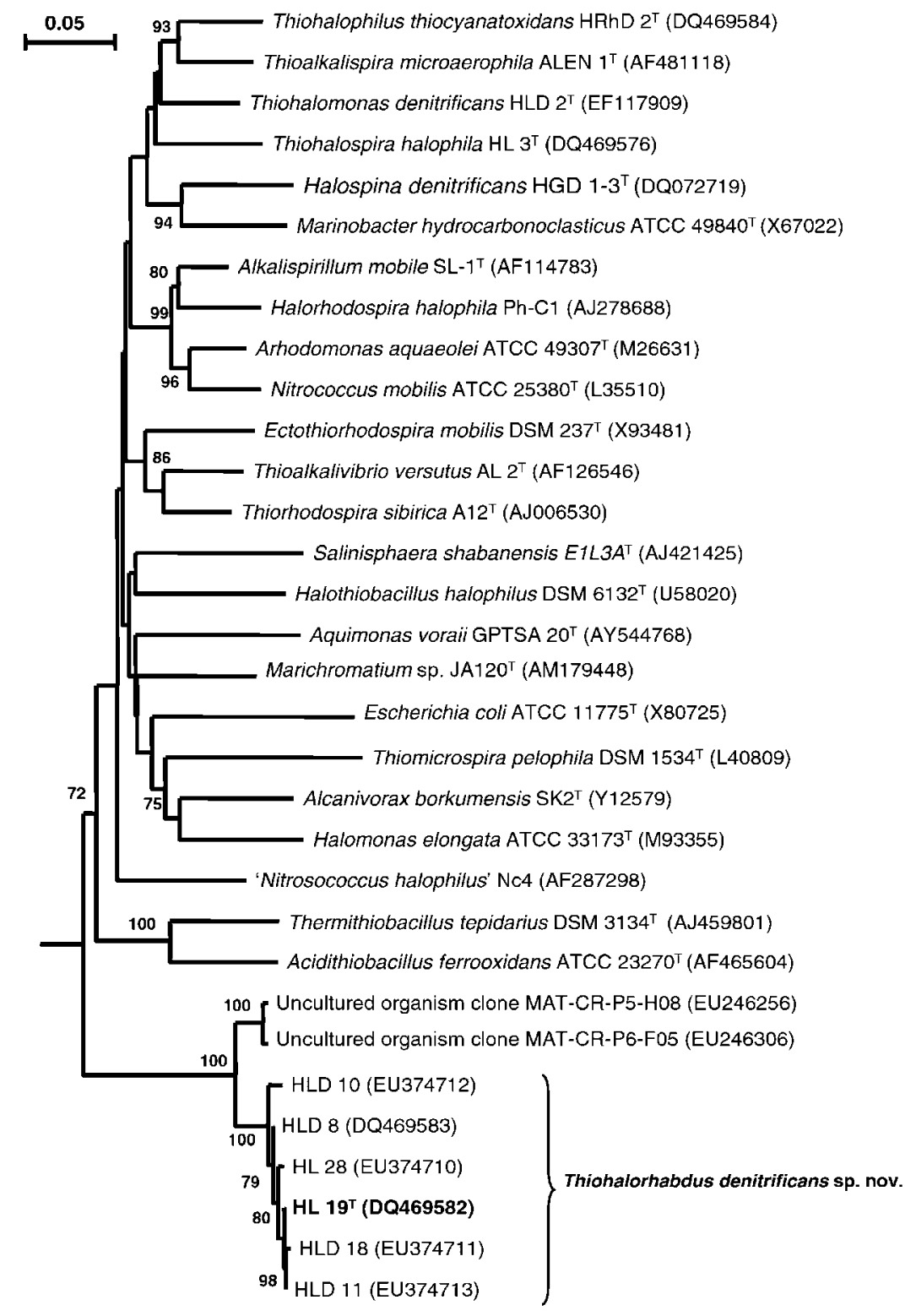

Fig. 4. Phylogenetic position of extremely halophilic, facultatively anaerobic SOB from hypersaline habitats within the class Gammaproteobacteria based on 16S rRNA gene sequence analysis. The tree was reconstructed from evolutionary distances by using the neighbour-joining (NJ) method. Values at nodes are the bootstrap percentages as derived from 1000 resamplings. Values $>70 \%$ were considered as significant. Bar, 0.05 substitutions per nucleotide position.

6.5 and 8.2 with an optimum at $\mathrm{pH}$ 7.3-7.8. The optimum growth temperature is $33-35{ }^{\circ} \mathrm{C}$. The $\mathrm{G}+\mathrm{C}$ content of the DNA is $65.0-65.8 \mathrm{~mol} \%\left(T_{\mathrm{m}}\right)$.

The type strain, HL $19^{\mathrm{T}} \quad\left(=\mathrm{DSM} \quad 15699^{\mathrm{T}}=\mathrm{UNIQEM}\right.$ $\mathrm{U}_{22}{ }^{\mathrm{T}}$ ) was isolated from a hypersaline lake in south-west Siberia (Russia). The $\mathrm{G}+\mathrm{C}$ content of the DNA of the type strain is $65.8 \mathrm{~mol} \%\left(T_{\mathrm{m}}\right)$. A reference strain, HLD 10 has been deposited as DSM 15703 (=UNIQEM U224).

\section{Acknowledgements}

This work was supported by the NWO-RFBR (grant 47.011.2004.010), RFBR (grant 07-04-00153) and by the Russian Academy of Sciences Program 'Molecular and Cell Biology'. We thank G. Osipov for the analysis of cellular fatty acids, K. Sjollema for thin section electron microscopy and A. Lysenko for total DNA analysis.

\section{References}

Banciu, H., Sorokin, D. Yu., Galinski, E. A., Muyzer, G., Kleerebezem, R. \& Kuenen, J. G. (2004). Thioalkalivibrio halophilus sp. nov., a novel obligately chemolithoautotrophic facultatively alkaliphilic and extremely salt-tolerant sulfur-oxidizing bacterium from a hypersaline alkaline lake. Extremophiles 8, 325-334.

De Ley, J., Cattoir, H. \& Reynaerts, A. (1970). The quantitative measurement of DNA hybridization from renaturation rates. Eur $J$ Biochem 12, 133-140.

Felsenstein, J. (1993). PHYLIP (phylogeny inference package), version 3.53c. Distributed by the author. Department of Genome Sciences, University of Washington, Seattle, USA. 
Isenbarger, T. A., Finney, M., Rios-Velazquez, C., Handelsman, J. \& Ruvkun, G. (2008). Miniprimer PCR, a new lens for viewing the microbial world. Appl Environ Microbiol 74, 840-849.

Marmur, J. (1961). A procedure for the isolation of deoxyribonucleic acid from microorganisms. J Mol Biol 3, 208-218.

Marmur, J. \& Doty, P. (1962). Determination of the base composition of deoxyribonucleic acid from microorganisms. J Mol Biol 5, 109-118.

Pfennig, N. \& Lippert, K. D. (1966). Über das Vitamin $B_{12}$-Bedürfnis phototropher Schwefelbakterien. Arch Microbiol 55, 245-256 (in German).

Schäfer, H. \& Muyzer, G. (2001). Denaturing gradient gel electrophoresis in marine microbial ecology. Methods Microbiol 30, 425-468.

Sorokin, D. Yu. (2008). Diversity of halophilic sulfur-oxidizing bacteria in hypersaline habitats. In Microbial Sulfur Metabolism, Proceedings of the International Symposium on Microbial Sulfur Metabolism 29 June-2 July 2006, Münster, Germany. Edited by C. Dahl \& C. G. Friedrich, pp. 225-237. Berlin: Springer.

Sorokin, D. Yu., Kuenen, J. G. \& Jetten, M. (2001). Denitrification at extremely alkaline conditions in obligately autotrophic alkaliphilic sulfur-oxidizing bacterium Thioalkalivibrio denitrificans. Arch Microbiol 175, 94-101.

Sorokin, D. Yu., Tourova, T. P. \& Muyzer, G. (2005). Oxidation of thiosulfate to tetrathionate by a haloarchaeon from hypersaline habitat. Extremophiles 9, 501-504.

Sorokin, D. Yu., Tourova, T. P., Lysenko, A. M. \& Muyzer, G. (2006a). Culturable diversity of halophilic sulfur-oxidizing bacteria in hypersaline habitats. Microbiology 152, 3013-3023.
Sorokin, D. Yu., Tourova, T. P., Kolganova, T. V., Spiridonova, E. M., Berg, I. A. \& Muyzer, G. (2006b). Thiomicrospira halophila sp. nov., a novel, moderately halophilic, obligately chemolithoautotrophic sulfur-oxidizing bacterium from hypersaline lakes. Int $J$ Syst Evol Microbiol 56, 2375-2380.

Sorokin, D. Yu., Tourova, T. P., Braker, G. \& Muyzer, G. (2007a). Thiohalomonas denitrificans gen. nov., sp. nov, and Thiohalomonas nitratireducens sp. nov., novel obligately chemolithoautotrophic, moderately halophilic, thiodenitrifying Gammaproteobacteria from hypersaline habitats. Int J Syst Evol Microbiol 57, 1582-1589.

Sorokin, D. Yu., Tourova, T. P., Bezsoudnova, E. Yu., Pol, A. \& Muyzer, G. (2007b). Denitrification in a binary culture and thiocyanate metabolism in Thiohalophilus thiocyanoxidans gen. nov. sp. nov. - a moderately halophilic chemolithoautotrophic sulfur-oxidizing Gammaproteobacterium from hypersaline lakes. Arch Microbiol 187, 441-450.

Sorokin, D. Yu., Tourova, T. P., Muyzer, G. \& Kuenen, J. G. (2008). Thiohalospira halophila gen. nov., sp. nov., and Thiohalospira alkaliphila sp. nov., novel obligately chemolithoautotrophic, halophilic, sulfur-oxidizing gammaproteobacteria from hypersaline habitats. Int J Syst Evol Microbiol 58, 1685-1692.

Van de Peer, Y. \& De Wachter, R. (1994). TREECON for Windows: a software package for the construction and drawing of evolutionary trees for the Microsoft Windows environment. Comput Appl Biosci 10, 569-570.

Zhilina, T. N., Zavarzin, G. A., Rainey, F. A., Pikuta, E. N., Osipov, G. A. \& Kostrikina, N. A. (1997). Desulfonatronovibrio hydrogenovorans gen. nov., sp. nov., an alkaliphilic, sulfate-reducing bacterium. Int J Syst Bacteriol 47, 144-149. 